\title{
TEKNOLOGI GARAM PALUNG SEBAGAI WARISAN SEJARAH MASYARAKAT PESISIR BALI
}

\author{
Yety Rochwulaningsih, Mahendra P. Utama, Singgih Tri Sulistiyono \\ Departemen Sejarah, Fakultas Ilmu Budaya, \\ Universitas Diponegoro,Semarang-Indonesia
}

Alamat korespondensi: wulan.psa.undip@gmail.com

Diterima/Received: 17 Februari 2019; Direvisi/Revised: 13 Maret 2019; Disetujui/Accepted: 23 Maret 2019

\begin{abstract}
This article aims to discuss the existence of palung salt technology as a variant of traditional solar evaporation-based salt production technology. This technology is very typical and has been used for generations by salt farmers in Bali, especially at Amed in Karangasem, Tejakula in Buleleng, and Kusamba in Klungkung. Historical and sociological method is used in this research. Palung salt technology is a historical inheritance that still functions as a cultural memory and therefore becomes a pattern for the actions of salt farmers in the three petasikan until recent time. However, since the beginning of the 21st century the preservation of palung salt technology have been faced a serious threat as a result of the inclusion of new technologies in the salt production process and especially by the growing tourism industry in palung salt production area. But, there is the awareness of stakeholders who need to preserve the technology by conducting various activities. Although carried out in a fragmentary method, efforts to preserve palung salt technology have become a shared awareness among stakeholders in the salt economy in Bali.
\end{abstract}

Keywords: Palung Salt; Historical Heritage; Tourism; Bali.

\section{Abstrak}

Artikel ini bertujuan untuk membahas eksistensi teknologi garam palung sebagai suatu varian dari teknologi produksi garam tradisional berbasis solar evaporation. Teknologi ini sangat khas dan telah digunakan secara turuntemurun oleh petani garam di Bali, khususnya di petasikan Amed di Kabupaten Karangasem, Tejakula di Kabupaten Buleleng, dan Kusamba di Kabupaten Klungkung. Artikel ini disusun berdasar penelitian historis dan sosiologis. Teknologi garam palung merupakan warisan sejarah yang masih berfungsi sebagai memori budaya dan oleh karena itu menjadi pola bagi tindakan petani garam di ketiga petasikan tersebut sampai masa ini. Namun demikian, sejak awal abad ke-21 kelestarian teknologi garam palung menghadapi ancaman serius sebagai akibat masuknya teknologi baru dalam proses produksi garam dan terutama oleh industri pariwisata yang semakin berkembang di daerah produsen garam palung. Namun terdapat kesadaran dari pemangku kepentingan yang telah memiliki kesadaran untuk menyelematkan teknologi tersebut dengan melakukan berbagai kegiatan. Meskipun dilakukan secara fragmentaris, tetapi usaha untuk melestarikan teknologi garam palung telah menjadi kesadaran bersama di kalangan pemangku kepentingan dalam ekonomi garam di Bali.

Kata Kunci: Garam Palung; Warisan Sejarah; Pariwisata; Bali.

\section{PENDAHULUAN}

Memproduksi garam merupakan mata pencaharian utama bagi sebagian penduduk pesisir Bali sejak berabad-abad yang lalu. Menurut salah seorang tokoh adat Bali, diketahui bahwa kawasan pesisir yang digunakan untuk memproduksi garam disebut petasikan (Wawancara dengan Ida Wayan Gangga, 9 Februari 2019).

Garam merupakan salah satu komoditas penting dalam perdagangan antara Bali, Lombok, dan Batavia dalam abad ke-17. Kapal-kapal dari Bali yang berlayar ke Batavia membawa muatan garam, di samping komoditas lainnya yaitu budak 
laki-laki dan perempuan, beras, gula, asam, babi, minyak kelapa, pinang, malam, dan kayu. Kapalkapal dari Lombok yang berlayar ke Batavia juga membawa muatan garam selain beras, kayu, dan budak perempuan. Sebaliknya, kapal-kapal yang datang dari Batavia membawa barang dagangan ke Bali berupa porselin, kain, besi tua, obatobatan, ikan asin, ketumbar, kemenyan, dan tembaga; sedangkan barang-barang dagangan yang masuk ke Lombok antara lain laken merah, ketumbar, peci, dan besi (Putra-Agung, 2001: 67).

Berdasar pemetaan yang dilakukan oleh Kementerian Kelautan dan Perikanan (KKP) pada 2010, daerah produsen garam di Indonesia diklasifikasikan menjadi daerah sentra dan daerah penyangga. Daerah sentra garam nasional meliputi sembilan kabupaten, yaitu Kabupaten Indramayu dan Cirebon (Jawa Barat); Pati dan Rembang (Jawa Tengah); Tuban, Sampang, Pamekasan, dan Sumenep (Jawa Timur); dan Nagekeo (Nusa Tenggara Timur). Daerah penghasil garam yang lain, termasuk Bali, dikategorikan sebagai daerah penyangga garam nasional (Direktorat Pemberdayaan Masyarakat Pesisir dan Pengembangan Usaha Kementerian Kelautan dan Perikanan Republik Indonesia, 2011: 4). Daerah penghasil garam di Bali berada di Kabupaten Gianyar, Karangasem, Buleleng, Tabanan, dan Klungkung. Sebagai daerah penyangga, kontribusi Bali dalam pemenuhan kebutuhan garam nasional tentu tidak dapat disetarakan dengan daerah sentra garam. Kebutuhan garam di Bali bahkan masih harus dipenuhi dengan mendatangkan garam dari Madura dan Nusa Tenggara Timur (Rochwulaningsih \& Utama, 2013: 131).

Pada 2011-2015 KKP melaksanakan program Pemberdayaan Usaha Garam Rakyat (PUGAR) untuk mencapai swasembada garam nasional yang telah dicanangkan pada 2010 . Program itu dilaksanakan di daerah sentra dan penyangga untuk meningkatkan produksi garam nasional melalui peningkatan luas lahan produksi, jumlah petani garam, dan penggunaan teknologi baru. Secara nasional program PUGAR dapat mencapai taget yang dibuktikan dengan keberhasilan Indonesia melakukan swasembada garam pada 2015 khususnya pada sektor garam konsumsi (Rochwulaningsih, 2017). Pemerintah masih harus mengimpor garam untuk memenuhi sebagian kebutuhan pada sektor garam industri. Kondisi itu terjadi pula di Bali. Peningkatan produksi garam di Bali melalui program PUGAR baru dapat memenuhi kebutuhan sektor garam konsumsi. Kebutuhan garam industri di provinsi ini harus dipenuhi dari luar Bali. Para pengusaha pemindangan di Kabupaten Klungkung, misalnya, sangat bergantung pada pasokan garam industri dari luar Bali baik yang berasal dari garam impor maupun garam dari Bima dan Madura yang sesuai dengan kebutuhan mereka, yaitu memiliki ukuran kristal lebih besar, padat, dan keras (Yogana, Putra \& Parining, 2016: 589).

Garam di Bali diproduksi dengan metode solar evaporation, yaitu memanfaatkan panas matahari untuk menguapkan air laut tua (bahasa Bali: nyah) sampai terbentuk kristal garam. ${ }^{2}$ Metode ini mengalami persamaan dan perbedaan di beberapa lokasi, seperti di Aceh (Rochwulaningsih, 2018) yang menggunakan metode perebusan. Petani garam Indonesia pada umumnya melakukan evaporasi di petak-petak pengkristalan (mejan garam) di lahan garam. Namun, di beberapa petasikan di Bali, evaporasi dilakukan dengan menggunakan sebuah medium yang disebut palung. Palung dibuat dari batang pohon tal (orang Bali menyebutnya ental) atau batang pohon kelapa dengan panjang sekitar 3,5-4 meter. Batang pohon itu dibelah menjadi dua dan masing-masing belahan itu dikeruk membentuk cekungan seperti lesung, yang selanjutnya digunakan untuk mengevaporasi nyah. Penggu-naan palung telah menciptakan suatu sistem teknologi produksi garam yang khas, yang dalam artikel ini disebut "teknologi garam palung". Teknologi pembuatan garam tradisional ini hanya terdapat di petasikan tertentu, antara lain di pesisir Amed Kecamatan Abang Kabupaten Karangasem, pesisir Tejakula Kecamatan Tejakula Kabupaten Buleleng, dan pesisir Kusamba Kecamatan Dawan Kabupaten Klungkung.

Dalam beberapa studi ditunjukkan bahwa proses produksi garam di Indonesia, khususnya di Jawa, pada umumnya merupakan usaha rumah tangga yang bersifat subsisten. Kegiatan ekonomi ini sangat rentan terhadap perubahan iklim dan cuaca karena selama berabad-abad proses produksi dan teknologi yang digunakan tidak mengalami perubahan yang substansial (Rochwu- 
laningsih, 2008). Usaha pembuatan garam tradisional di Indonesia juga menghadapi berbagai persoalan. Petani garam di Jawa, misalnya, mengalami marjinalisasi secara sosioekonomis sebagai akibat dari terjadinya polarisasi dalam penguasaan lahan dan dominasi mode produksi kapitalis. Mereka yang memiliki lahan kecil dapat bergeser menjadi penggarap atau pekerja. Sebagian dari mereka bahkan tidak mampu bertahan hidup dengan usaha mereka sehingga meninggalkannya untuk beralih ke pekerjaan yang lain. Lahan merupakan faktor produksi dan media produksi yang sangat penting dalam ekonomi garam. Struktur kepemilikan lahan akan menentukan akses petani terhadap surplus produksi mereka. Petani garam yang tidak memiliki lahan hanya memiliki akses yang rendah atau bahkan sama sekali tidak memiliki akses terhadap surplus produksi. Sebaliknya, petani yang memiliki lahan yang luas mempunyai akses yang lebib besar untuk menikmati surplus produksi. Struktur kepemilikan lahan juga berpengaruh pada mode produksi. Mode produksi kapitalis hanya dapat dijalankan oleh petani dengan lahan luas, sedangkan petani dengan lahan kecil berbasis pada mode produksi non-kapitalis atau usaha rumah tangga (Rochwulaningsih, 2013).

Karakteristik dan persoalan dalam usaha garam di Jawa dapat ditemukan pula di Bali. Dalam sebuah studi awal dilaporkan bahwa hubungan produksi dalam usaha garam di Bali cenderung bersifat egaliter. Hal itu karena usaha rumah tangga itu merupakan basis subsistensi dan tidak terutama dikelola atas perhitungan untungrugi. Namun demikian ekonomi garam di Bali juga menghadapi persoalan serius sebagai akibat dari ekspansi ekonomi kapitalis. Petani garam tidak dapat melakukan ekspansi pasar biarpun secara aktual mereka memiliki kesempatan yang sama. Dalam ekonomi garam berbasis teknologi palung, ekspansi pasar dilakukan dengan membuat produk yang mendapat pengakuan unik melalui pengemasan yang inovatif, atraktif, dan hegienis serta memiliki lisensi dan paten sehingga dapat dijual dengan harga tinggi dan dipasarkan sampai ke mancanegara. Selain memerlukan banyak biaya, banyak pula persyaratan yang sulit dipenuhi oleh petani garam secara perorangan. Sampai pada 2012 hanya ada satu perusahaan garam di Buleleng yang dapat melakukannya. Fakta ini sekaligus memperlihatkan bahwa ekspansi pasar lebih mungkin untuk dilakukan oleh pemilik modal. Kesulitan untuk mengakses pasar yang lebih luas telah menyurutkan minat petani garam palung untuk mempertahankan usaha mereka. Sebagian dari mereka beralih ke pekerjaan lain dan bahkan ada yang menjual lahan garam mereka kepada pemilik modal yang kemudian memanfaatkannya untuk membangun akomodasi wisata. Industri pariwisata yang semula terpusat di Bali selatan memang telah mulai merambah hingga ke daerah petasikan di Bali bagian utara dan timur (Rochwulaningsih \& Utama, 2013).

Menurunnya minat untuk mempertahankan usaha pembuatan garam yang dibarengi dengan alih fungsi lahan untuk melayani kepentingan pariwisata dapat mengancam eksistensi teknologi garam palung. Ancaman itu bukannya tidak disadari, tetapi bahkan telah mendapatkan perhatian dari pemerintah, kelompokkelompok petani garam palung, dan para pengusaha garam dan pariwisata. Berkaitan dengan itu, dalam artikel ini akan dibahas mengenai eksistensi teknologi garam palung khususnya di Amed, Tejakula, dan Kusamba sebagai warisan sejarah masyarakat pesisir Bali. Pembahasan akan fokuskan pada arti penting pelestarian teknologi produksi garam palung dan kegiatan-kegiatan telah dilakukan oleh para pemangku kepentingan serta kontribusinya bagi kelestarian teknologi garam palung.

\section{METODE}

Data dalam artikel ini diperoleh melalui studi pustaka, studi dokumen, dan kajian lapang. Studi pustaka dilakukan dengan menelaah hasil penelitian sejenis yang telah dipublikasikan baik dalam buku dan jurnal. Studi pustaka juga dilakukan dengan memanfaatkan artikel-artikel surat kabar. Studi dokumen dilakukan dengan menelaah arsip-arsip dari Dinas Peternakan, Kelautan dan Perikanan Kabupaten Karangasem dan Kabupaten Klungkung, serta dokumendokumen yang berkaitan dengan Desa Adat Culik di Kecamatan Abang Kabupaten Karangasem. Kajian lapang bertujuan untuk mengumpulkan data melalui observasi dan wawancara. Observasi 
dilakukan dengan mengamati kondisi lingkungan alam di petasikan, kegiatan-kegiatan dalam proses produksi garam palung, dan berbagai peralatan yang digunakan. Pengumpulan data melalui observasi juga dilakukan secara ex-post facto (Sevilla et al., 1993: 145) dengan mengamati fotofoto yang berkaitan dengan garam palung milik kelompok petani garam di Tejakula dan Amed serta Hotel Uyah Amed \& Spa-Resort, serta film dokumenter berjudul "PUGAR Merenda Asa". Sementara itu wawancara dilakukan dengan para informan yang diseleksi dengan teknik snowball sampling (Bogdan \& Knopp, 1982). Mereka terdiri atas petani garam, ketua kelompok petani garam, tokoh adat, pengusaha garam, dan pelaku usaha pariwisata.

\section{BEBERAPA VARIASI DALAM PROSES PRODUKSI GARAM PALUNG}

Baik jenis maupun tahapan pekerjaan dalam proses pembuatan garam berbasis teknologi palung di petasikan Amed, Tejakula, dan Kusamba memperlihatkan banyak kesamaan. Namun, apabila dilihat dari proses pengolahan air laut menjadi nyah, bentuk palung, cara evaporasi, dan alat yang digunakan untuk memanen garam dari palung, akan tampak sejumlah perbedaan antara proses produksi garam palung di Amed dan Tejakula di satu sisi dengan di Kusamba di sisi yang lain. Mengacu pada Rochwulaningsih \& Utama (2013: 133-157) dan ilm dokumenter "PUGAR Merenda Asa", proses produksi garam palung dapat diuraikan secara ringkas sebagai berikut.

Petani garam palung di Amed dan Tejakula memulai pekerjaan mereka dengan menyiapkan tulud, yaitu sebidang lahan yang akan digunakan untuk membuat adonan untuk memproses air laut menjadi nyah. Mula-mula mereka membersihkan tulud dari rumput dan batu-batu kecil, membaginya menjadi empat bagian dengan membuat pematang, kemudian meratakan dan memadatkan permukaannya sambil menyiraminya dengan air laut. Setelah permukaan tulud mengering, mereka menaburkan tanah gunung, yang oleh petani setempat disebut tanah sari, secara merata dan menyiraminya dengan air laut secara berulang hingga empat atau lima kali. Penyiraman kedua dan seterusnya dilakukan setelah tanah sari mengering. Sesekali mereka membalik tanah sari dengan bangkrak ${ }^{3}$ agar tersiram air laut secara merata. Air laut diambil dengan menciduknya langsung dari laut dengan sene, yaitu wadah yang dibuat dari pelepah ental atau seng, lalu memikulnya ke tulud. Penyiraman secara berulang kali dimaksudkan agar tanah sari memiliki kandungan garam yang tinggi karena akan dipakai sebagai media untuk membuat nyah.

Setelah penyiraman terakhir, tanah sari yang telah mengering dikeruk dan dikumpulkan menjadi beberapa gundukan. Selanjutnya tanah sari itu dimasukkan ke dalam tinjungan, yakni wadah berbentuk kerucut terbalik yang disangga dengan tiang-tiang dari bambu dan terletak pada titik pertemuan keempat bidang tulud. Tanah sari yang telah berada di dalam tinjungan disiram lagi dengan air laut hingga tiga atau empat kali penyiraman. dan setelah itu harus diganti karena kandungan garamnya telah semakin berkurang.

Dari penyiraman tanah sari itu dihasilkan nyah, yang ditampung di dalam brombong atau bak yang terletak di bawah tinjungan. Nyah selanjutnya dibawa dengan cara dipikul menggunakan sene untuk dievaporasi di palung. Pengisian palung dengan nyah dilakukan menggunakan sibuh atau gayung dari tempurung kelapa. Palung ditata rapat menjadi beberapa deret di atas penopang dari bambu dengan ketinggian sekitar $30 \mathrm{~cm}$ dari permukaan tanah. Garam dipanen setelah proses evaporasi selama tiga hingga empat hari. Dalam kondisi cuaca yang tidak menentu, pengambilan garam dari palung dapat dilakukan lebih cepat bairpun evaporasi belum mencapai tiga hari. Hal ini dilakukan karena kristal garam tidak akan terbentuk apabila nyah di dalam palung terkena atau tercampur dengan air hujan. Alat pengeruk garam dibuat dari ember kecil atau kaleng cat bekas yang diberi tangkai panjang sehingga pengerukan dapat dilakukan dari salah satu sisi deretan palung. Garam yang telah dikeruk itu ditiriskan terlebih dahulu di dalam wadah dari anyaman bambu. Setelah tidak ada lagi air yang menets, garam selanjutnya dimasukkan ke dalam karung.

Semua tahap pekerjaan di atas dilakukan pula oleh petani garam palung di Kusamba. Hanya ada beberapa perbedaan terkait dengan media yang digunakan untuk membuat air tua dan bentuk palung. Petani garam di Kusamba tidak 
memakai tanah sari, melainkan pasir pantai yang berwarna hitam, sebagai media untuk membuat air tua. Penggunaan pasir sebagai media untuk membuat air tua tentu lebih menghemat biaya karena petani tidak perlu membeli tanah gunung. Mereka juga tidak memerlukan lahan khusus untuk tulud karena media itu dapat dibuat secara langsung pada hamparan pasir pantai dengan meratakannya lebih dahulu dan kemudian menyiramnya dengan air laut antara tiga hingga empat kali. Jarak dari laut yang hanya berkisar 10 meter membuat mereka dapat menghemat waktu dan tenaga untuk memikul air laut ke lokasi penyiapan media.

Pasir pantai yang telah diproses menjadi media itu selanjutnya dimasukkan ke dalam belong, yaitu bak dari papan kayu dan diguyur dengan air laut untuk mendapatkan nyah yang ditampung di brombong. Pasir media digunakan untuk dua kali penyiraman saja. Kemungkinan kandungan garam dalam pasir media lebih cepat habis apabila dibandingkan dengan kandungan garam dalam tanah sari. Oleh karena itu, setelah dua kali penyiraman, belong harus diisi dengan pasir media yang baru. Berbeda dari pembuatan nyah di Amed dan Tejakula yang berlangsung di tempat terbuka (di tulud), di Kusamba pekerjaan ini dilakukan di dalam gubug.

Perbedaan lainnya dapat dilihat pada cara menata palung. Di Kusamba, palung ditata memanjang dengan menggabungkan tiga buah palung menjadi satu lajur. Setiap lajur palung ditata di atas penopang dari bambu dengan ketinggian sekitar satu meter dari permukaan tanah. Di antara lajur palung diberi jarak sekitar setengah meter. Cara penataan yang demikian itu memungkinkan petani untuk menaruh air tua ke dalam palung dan mengeruk garam yang dihasilkan dengan posisi tubuh tetap berdiri tegak. Adanya jarak yang cukup lebar di antara lajur palung juga membuat mereka dapat mengeruk garam cukup dengan menggunakan sibuh tanpa tangkai. Bagian lahan pantai yang digunakan untuk menempatkan palung berjarak sekitar lima hingga tujuh meter dari tempat menyiapkan pasir media.

Berbeda dari palung di Amed dan Tejakula yang dibiarkan terbuka, palung yang digunakan oleh petani garam di Kusamba diberi penutup. Kerangka penutupnya dibuat dari belahan bambu, sedangkan atapnya dari daun kelapa. Garam yang dihasilkan dari palung yang ditutup terhindar dari debu atau kotoran lain yang terbawa angin sehingga kristal garamnya terlihat lebih bersih dan cerah.

Seluruh pekerjaan dalam proses pembuatan garam palung di Amed, Tejakula, dan Kusamba dilakukan baik oleh laki-laki maupun perempuan. Dalam keseluruhan tahap pekerjaan mulai dari menyiapkan tulud, membuat tanah sari dan pasir sebagai media untuk membuat nyah, dan memikul air dari laut hingga memanen garam dari palung tidak terdapat pembagian kerja yang spesifik antara laki-laki dan perempuan.

\section{TEKNOLOGI GARAM PALUNG SEBAGAI WARISAN SEJARAH}

Sampai saat ini belum diperoleh sumber-sumber yang dapat memberikan informasi yang cukup akurat mengenai awal berkembangnya teknologi garam palung di Bali. Apabila petasikan diasumsikan telah muncul sejak lahirnya desadesa adat di Bali, maka teknologi garam palung memang sudah sangat tua. Dalam prasasti Pura Mbudan Toya, misalnya, dinyatakan bahwa Desa Adat Culik berdiri pada Içaka 500 atau 578 Masehi. ${ }^{4}$ Petasikan di pesisir Amed merupakan bagian dari wilayah Desa Adat Culik. Namun demikian, dalam prasasti itu tidak ditemukan istilah petasikan.

Terlepas dari adanya kesulitan untuk membuat perkiraan mengenai awal berkembangnya teknologi garam palung di Amed, Tejakula, dan Kusamba, ${ }^{5}$ informasi yang sepotong-sepotong itu kiranya cukup untuk sekadar menunjukkan bahwa pembuatan garam palung telah berlangsung dari generasi ke generasi. Dalam kasus Amed, petani garam di petasikan itu hanya memproduksi garam palung. Dengan demikian dapat dikatakan bahwa proses produksi garam di Amed sejak semula dilakukan menggunakan teknologi garam palung. Kemungkinan hal yang sama juga terjadi pada petasikan Tejakula dan Kusamba.

Meminjam konsep dari Kaplan dan Manners, teknologi garam palung merupakan suatu bentuk tekno-ekonomi, yaitu teknologi yang berhubungan dengan mata pencaharian. Teknologi tidak hanya mengacu pada peralatan 
yang digunakan dalam kegiatan produktif, tetapi juga sistem pengetahuan dan sistem nilai yang ada di balik kegiatan produktif itu dan mengenai cara menjalankannya (Kaplan \& Manners, 2000: 6465). Tekno-ekonomi ini telah ditransmisikan dari generasi ke generasi sehingga menjadi bagian dari memori kolektif masyarakat petani garam palung. Memori kolektif berisi keyakinan, perasaan, dan penilaian moral mengenai masa lalu yang diinternalisasi melalui sosialisasi dan pembiasaan. Memori kolektif disebut pula memori budaya karena dijadikan acuan bagi generasi yang lebih kemudian untuk bertindak dan merekonstruksi identitas mereka. Dalam garis ini, dilihat dari sudut pandang generasi saat ini, memori kolektif atau memori budaya sejatinya merupakan warisan sejarah. Setiap masyarakat mempunyai kecenderungan untuk melestarikan memori budaya mereka melalui berbagai tradisi (Rodriguez \& Fortier, 2007: 1, 10, 108). Berdasar pemahaman ini, fakta bahwa teknologi garam palung masih fungsional dalam pengertian menjadi memori budaya dalam masyarakat petani garam palung di Amed, Tejakula, dan Kusamba menjadi salah satu alasan penting untuk mempertahankan eksistensinya.

Teknologi garam palung dikembangkan sebagai hasil adaptasi dengan lingkungan alam dan lingkungan sosial. Lokasi petasikan di Amed, Tejakula, dan Kusamba berada pada titik pertemuan antara bukit dan pantai. Selain berada pada tempat yang relatif tinggi, kebanyakan petasikan terletak cukup jauh dari laut dengan jarak sekitar 30 meter. Hanya di Kusamba lahan yang digunakan untuk menyiapkan pasir media dan untuk menata palung berjarak sekitar 10 meter saja dari laut. Jenis tanah di ketiga petasikan itu juga bukan berupa tanah liat yang setelah dipadatkan menjadi kedap air, tetapi merupakan tanah coklat kekuningan, seperti di perbukitan, bercampur dengan kerikil dan pasir. Komposisi ini tampaknya telah menyebabkan bagian bawah tanah petasikan memiliki banyak rongga sehingga tidak dapat menahan air laut biarpun permukaan lahannya telah dipadatkan. Air laut yang disiramkan ke atas permukaan lahan itu akan segera terserap habis ke dalam tanah. Tekstur tanah yang demikian itu jelas tidak memungkinkan evaporasi secara langsung di petak-petak lahan garam. Gambaran mengenai lokasinya yang cukup tinggi dari permukaan air laut dan tekstur tanah yang berongga dan tidak kedap air itu dapat menjelaskan pula mengapa di ketiga petasikan untuk garam palung itu tidak dilengkapi dengan saluran primer maupun sekunder seperti yang lazim ditemukan di daerah produsen garam di Indonesia. Itu pula sebabnya air laut yang akan diproses menjadi nyah harus diambil langsung dari laut dengan menggunakan wadah yang dapat dipikul.

Petani garam palung di Amed dan Tejakula membuat nyah dengan media tanah sari. Proses pembuatannya tidak memerlukan lahan yang luas karena hanya digunakan untuk menyiapkan tanah sari dengan menebarkan tanah gunung secara merata di atas permukaan lahan dengan ketebalannya sekitar $5 \mathrm{~cm}$. Tanah sari harus disiram dengan air laut empat atau lima kali agar memiliki kandungan garam yang tinggi. Petak lahan yang digunakan untuk menyiapkan tanah sari di kedua petasikan itu pada umumnya berukuran panjang sekitar 7 meter dan lebar sekitar 5 meter. Petani garam palung di Kusamba bahkan tidak memerlukan lahan khusus karena mereka menggunakan pasir pantai sebagai media untuk membuat nyah. Mereka hanya perlu memilih bagian pantai yang cukup datar, meratakan permukaannya, menggemburkan atau mengurai pasir yang telah memadat, dan kemudian menyiraminya dengan air laut.

Tampak bahwa teknologi pembuatan garam palung secara keseluruhan memperlihatkan kecerdikan petani garam di ketiga petasikan itu untuk tetap dapat memproduksi garam sementara lingkungan alam, terutama kondisi topografis dan tekstur tanah, kurang mendukung kegiatan ekonomi itu. Selain melalui berbagai jenis dan tahap kegiatan sebagaimana dideskripsikan di atas, adaptasi terhadap lingkungan alam dapat dilihat pula dari berbagai jenis peralatan yang kebanyakan dibuat secara tradisional dengan bahan-bahan yang berasal dari alam. Untuk sekadar contoh adalah pemanfaatan bambu dan pohon kelapa sebagai bahan untuk membuat peralatan pokok seperti tinjungan, palung, penutup palung, sibuh, dan wadah untuk meniriskan garam yang baru dipanen. Tentu saja ada peralatan dari bahan-bahan yang tidak berasal dari alam, misalnya alat pengeruk garam yang dibuat 
dengan memanfaatkan ember plastik dan bekas kaleng cat.

Sementara itu adaptasi terhadap lingkungan sosial tercermin dari organisasi kerja yang berbasis pada keluarga inti. Pekerjaan-pekerjaan dalam pembuatan garam palung ditangani oleh anggota keluarga. Di Kusamba, seorang petani garam perempuan bahkan sanggup mengerjakan semua jenis pekerjaan seorang diri, mulai dari membersihkan dan meratakan pasir pantai, memikul air laut untuk membuat pasir media dan menyiramnya setelah dimasukkan ke dalam belong sampai dengan mengeruk garam dari palung ("PUGAR Merenda Asa”, 2012). Dengan demikian secara umum organisasi kerja dalam proses produksi garam palung relatif kecil karena hanya melibatkan anggota keluarga inti. Tidak ada jenis pekerjaan yang memerlukan keterlibatan banyak orang. Masuknya tenaga kerja selain anggota keluarga inti memang dimungkinkan tetapi hanya sebagai tenaga pengganti, misalnya ketika salah satu anggota keluarga inti sedang sakit atau harus melaksanakan kegiatan lain yang tidak dapat ditunda. Petani garam palung mengutamakan untuk mencari tenaga kerja pengganti dari kerabat mereka sendiri. Tidak adanya pekerjaan yang melibatkan banyak tenaga kerja dapat dihubungkan dengan kenyataan bahwa proses produksi garam palung tidak memerlukan lahan yang luas.

Oleh karena organisasi kerjanya berbasis pada keluarga inti, menjadi hal biasa jika pada saat bekerja para petani membawa anak-anak mereka. Melalui pola pengasuhan ini pengetahuan dan keterampilan membuat garam palung tersosialisasi kepada anak-anak. Pengalaman Sinupring, seorang petani garam palung di Kusamba, dapat menggambarkan transmisi pengetahuan tentang cara membuat garam. Sejak kecil ia sering diajak oleh orang tuanya saat mereka membuat garam. Mula-mula ia hanya bermain dan melihat ayah dan ibunya membuat garam. Ia tidak dapat melanjutkan pendidikan dasar karena orang tuanya tidak mampu membiayai sekolahnya. Oleh karena itu, ia lebih banyak menghabiskan hariharinya bersama orang tuanya di tempat pembuatan garam. Ia mulai melibatkan diri dalam proses pembuatan garam dengan melakukan pekerjaan-pekerjaan yang ringan dan saat remaja telah mampu membuat garam sendiri. Setelah menikah, ia dan suaminya menjadikan usaha membuat garam palung sebagai mata pencaharian ("PUGAR Merenda Asa", 2012; Wawancara dengan Sinupring, 23 Maret 2018).

Bentuk lain dari adaptasi sosial adalah irama kerja dalam proses pembuatan garam palungyang disesuaikan dengan kegiatan adat dan keagamaan. Petani garam akan menghentikan aktivitas mereka sehari penuh ketika pada hari itu ada upacara keagamaan atau kegiatan adat lainnya seperti gotong royong. Mereka harus mengikuti kegiatan itu sebagai kewajiban warga desa adat. Orang yang melanggar aturan adat ini akan dikenai sanksi berupa denda di samping sanksi sosial misalnya dijadikan bahan pembicaraan oleh warga desa. Sanksi sosial ini dirasakan sebagai suatu yang memalukan ("PUGAR Merenda Asa", 2012).

Dalam berbagai kebudayaan di dunia, garam memiliki tempat khusus dalam sistem keyakinan sehingga digunakan untuk tujuan-tujuan simbolis. Masyarakat Mesir, misalnya, sejak sekitar 4000 tahun yang lalu sudah memanfaatkan garam untuk upacara keagamaan dan berbagai praktik supranatural termasuk untuk pengobatan ("History of Salt", http://www.saltinstitut.org/ 38.html, diakses pada 22 Desember 2017). Sementara itu suku-suku Indian di Amerika Tengah menjadikan garam sebagai unsur penting dalam upacara dan ritual. Pada masa primitif, mereka harus menempuh perjalanan yang jauh dan berbahaya untuk mendapatkan garam yang dihasilkan secara alamiah dari danau garam. Bahkan, mereka kadang-kadang harus berperang ketika ada suatu suku ingin menguasa danau garam itu dan menutup akses bagi suku lainnya. Begitu penting arti garam sehingga suku-suku Indian memiliki Dewi Garam. Penggunaan garam untuk tujuan simbolis di kalangan suku Indian di Amerika Tengah masih ditemukan pada masa kontemporer (Gilmore, 1955: 1011-1012). Fenomena semacam itu juga ditemukan di Bali. Garam selalu ada dalam banten (sesaji) sebagai unsur yang diyakini mampu menangkal kekuatan jahat. Orang Bali juga menganggap bahwa garam merupakan syarat minimal yang harus dipenihi untuk lauk sehari-hari. Oleh karena itu, setiap selesai memasak, mereka akan memberi sesaji berupa nasi yang diberi garam di samping unsur lain seperti bunga-bunga. Sesaji itu harus 
diberikan sebelum mereka menyantap makanan yang telah selesai dimasak, sebagai ucapan terima kasih kepada roh-roh yang telah melindungi mereka (Wawancara dengan Nengah Suanda, 9 Februari 2019).

Teknologi garam palung mendorong komunitas petani garam untuk mengembangkan sistem pengetahuan dan nilai-nilai yang mendukung kelestarian lingkungan karena keberlangsungannya harus ditopang dengan bahanbahan dari alam. Kelestarian pohon kelapa, misalnya, tidak hanya penting bagi usaha garam palung. Berbagai peralatan dalam kehidupan sehari-hari dan upacara juga dibuat dari bahanbahan yang diambil dari pohon kelapa. Sebagai contoh adalah tetaring (atap rumah dan bale banjar yang dibuat dari daun kelapa yang ditata dan dijepit dengan bambu), klangsah (alas duduk dari anyaman daun kelapa), ingke (piring dari anyaman lidi), anyaman daun kelapa untuk wadah banten, dan tamiang (hiasan dari daun kelapa) (Kurnianingsih, 2004: 1-4).

Teknologi garam palung juga berperan penting sebagai kekuatan penggerak dalam pertukaran jaringan antardesa. Di Amed, misalnya, beberapa peralatan seperti palung, tinjungan, dan gangan tidak diproduksi di Amed sendiri maupun Desa Adat Culik. Bahan-bahan untuk membuat palung dan tinjungan dibeli dari dan dikerjakan oleh para perajin dari Desa Kesimpar, tetapi pengerjaannya dilakukan langsung di petasikan Amed. Harga palung mencapai Rp 200 ribu per buah, sedangkan tinjungan $\mathrm{Rp} 800$ ribu per buah. Sementara itu gangan dibeli dari Kesimpar sebagai produk yang sudah jadi (Wawancara dengan Nengah Suanda, 9 Februari 2019). Dalam bentuk yang lain, pertukaran ekonomi juga terjadi melalui kegiatan upacara yang diikuti oleh beberapa desa. Selain babi dan perlengkapan lain, desa adat Culik selalu diharapkan membawa garam guna memenuhi kebutuhan upacara, baik sebagai bumbu masak maupun untuk kelengkapan banten (Wawancara dengan Ida Wayan Gangga, 10 Februari 2019). Sudah tentu garam menjadi alat tukar yang penting. Seorang informan yang telah mulai membuat garam sejak masa pendudukan Jepang mengatakan bahwa sampai sekitar 1970-an masih bisa "membayar" beras dengan menggunakan garam (Wawancara dengan Nengah Nungkrah, 23 Maret 2018).

Surpha (2004: 8-9) menyatakan bahwa kehidupan masyarakat di desa-desa adat di Bali selalu diliputi oleh Tri Hita Karana yang mencakup tiga gagasan sentral yaitu keselarasan dalam hubungan antarsesama, keselarasan dengan alam, dan keselarasan dengan dunia supernatural. Tri Hita Karana menjadi dasar filosofis dan religius dari desa adat di Bali sehingga akan terjelma ke dalam setiap aspek kehidupan masyarakatnya. Gambaran yang telah dikemukakan di atas kiranya dapat memperlihatkan bagaimana Tri Hita Karana mewujud dalam berbagai praktik hidup yang berkaitan dengan teknologi garam palung.

\section{UPAYA PELESTARIAN TEKNOLOGI GARAM PALUNG}

Paling tidak sejak pertengahan dasawarsa abad ke21 telah tampak ancaman terhadap eksistensi teknologi garam palung. Di Tejakula, misalnya, jumlah petani garam palung dan areal petasikan mulai berkurang. Harga garam yang tidak menentu dan cenderung menurun membuat beberapa petani beralih ke pekerjaan lain dan menjual lahan garam mereka kepada para pemilik modal. Sejak itu mulai bermunculan bangunan untuk akomodasi pariwisata di petasikan (Rochwulaningsih \& Utama, 2013: 150-151). Pelaksanaan program PUGAR pada 2011-2015 telah membangkitkan kembali minat petani untuk bertahan dengan usaha mereka dan dengan demikian juga teknologi garam palung. Di Kabupaten Karangasem, pelaksanaan program PUGAR pada tiga tahun pertama berhasil meningkatkan luasan lahan produksi yaitu dari 6,76 Ha pada 2011 menjadi 8,21 Ha pada 2012 dan meningkat lagi menjadi 10,42 pada 2013. Jumlah petani garam juga terus bertambah dari 227 orang pada 2011 menjadi 298 orang pada 2012 dan menjadi 338 orang pada 2013. Sementara itu hasil produksi dalam tiga tahun itu fluktuatif sebagai akibat dari kondisi cuaca yang tidak stabil terutama pada musim garam 2013. Pada 2011 hasil produksi garam mencapai 611.000 ton, yang meningkat menjadi 919.967 ton pada 2012, tetapi kemudian menurun menjadi 578.750 ton pada $2013 .{ }^{6}$ 
Kajian lapang di Amed, Tejaku, dan Kusamba pada 2018 dan 2019 memperlihatkan temuan yang cukup mengejutkan. Luas areal untuk proses produksi garam palung di ketiga petasikan itu ternyata menyusut lagi dan cenderung semakin parah. Sebagian lahan garam palung telah beralih ke tangan para pemilik modal dan dikonversi menjadi sarana akomodasi pariwisata. Di Amed bahkan terjadi penurunan secara drastis luas lahan garam palung. Setelah berakhirnya program PUGAR, luas arel petasikan itu sekitar 780 are. Akan tetapi, pada 2017 sebagian besar areal garam palung di Amed telah beralih fungsi menjadi akomodasi wisata. Lahan petasikan yang tersisa tinggal 185 are dan benarbenar telah terkepung oleh bangunan-bangunan untuk kepentingan pariwisata terutama villa, cottage, café, dan restoran (Tribun Bali, 11 Agustus 2017). Petasikan di Tejakula juga semakin terdesak oleh bangunan akomodasi wisata sehingga produksi garam palung dilakukan pada lahan yang berbatasan langsung dengan laut. Sementara itu di Kusamba, menyempitnya areal petasikan berbasis teknologi palung lebih disebabkan oleh pembangunan rumah-rumah baru di tepi pantai dan pengembangan pelabuhan tradisional Tribuana yang melayani pelayaran ke Nusa Penida.

Perubahan itu barangkali tidak mengherankan mengingat pentingnya pariwisata dalam perekonomian Bali, tetapi tetap saja mengejutkan karena terjadi sangat cepat. Pariwisata telah terlanjur memanjakan orang Bali dan membentuk cara berpikir mereka menjadi pragmatis dan konsumtif. Mereka ingin meningkatkan kualitas ekonomi secara cepat dengan mengambil jalan pintas, yaitu menjual lahan sebagaimana diperlihatkan oleh para petani garam palung di Amed, Tejakula, dan Kusamba. Tindakan mereka memang tidak dapat dilarang karena lahan yang mereka jual merupakan gunakaya atau milik pribadi (Ida Wayan Gangga, 9 Februari 2019; dan Nengah Suanda, 10 Februari 2019). Menurut Windia (2008: 11-14), menjual lahan milik pribadi maupun tanah desa yang tidak terkendali akan merusak palemahan desa adat. ${ }^{7}$

Dalam situasi itu muncul kesadaran di kalangan para pemangku kepentingan. Pariwisata ternyata tidak hanya menciptakan kemakmuran, tetapi juga pemiskinan lingkungan yang merugikan para petani garam palung sendiri. Mereka berusaha menyelamatkan teknologi garam palung agar tidak semakin terkikis. Dinas Kelautan dan Perikanan Kabupaten Buleleng, sebagai contoh, melakukan upaya melestarikan teknologi tradisional itu dengan mengembangkan desa wisata garam di petasikan Tejakula. Petani garam palung di petasikan itu juga telah membentuk koperasi garam "Sarining Pertiwi". Melalui koperasi ini, garam palung setempat dapat segera terserap pasar terutama untuk menyuplai kebutuhan PT Neologis, sebuah perusahaan garam milik investor dari Jepang. Perusahaan ini hanya mau membeli garam palung, yang selanjutnya diolah dan dipasarkan sampai ke Hongkong, Korea, dan Jepang (Rochwulaningsih \& Utama, 2013: 144). Langkah terobosan seperti ini memberi sumbangan penting bagi peningkatan kesejahteraan ekonomi para petani garam dan kelestarian teknologi garam palung. Dengan dukungan pengusaha ini pula, kelompok petani garam di Tejakula sejak 2017 memiliki sebuah galeri yang dibangun di depan cottage di dekat areal produksi garam palung. Wisatawan yang datang ke sini dapat melihat foto-foto atau melihat secara langsung proses produksi garam palung.

Upaya untuk melestarikan dan mengembangkan teknologi garam palung di Tejakula juga dilakukan oleh Kementerian Kelautan dan Perikanan bekerja sama dengan Pemerintah Kabupaten Buleleng. Pada 2014 kedua instansi itu mengusulkan teknologi garam palung di Tejakula sebagai pusaka dunia melalui Globally Important Agricultural Heritage System yang digagas oleh Food Agriculture Organization. Berdasar pada pedoman UNESCO, ada beberapa kriteria yang harus dipenuhi untuk mengusulkan warisan sejarah dan budaya sebagai pusaka dunia, yaitu: (1) mewakili pencapaian artistik yang unik, sebuah mahakarya kreatif, jenius; atau (2) telah memberikan pengaruh besar, dalam rentang waktu atau dalam budaya wilayah dunia, tentang perkembangan arsitektur, seni monumental atau perencanaan kota dan desain lansekap; atau (3) memberikan kesaksian unik atau paling tidak luar biasa untuk suatu peradaban atau tradisi budaya yang telah punah; atau (4) menjadi contoh luar biasa dari jenis bangunan atau ansambel arsitektur atau bentang alam yang menggambarkan tahap 
signifikan dalam sejarah manusia; atau (5) menjadi contoh luar biasa dari pemukiman manusia tradisional atau penggunaan lahan yang mewakili suatu budaya (atau budaya), terutama ketika ia telah menjadi rentan di bawah dampak perubahan; atau (6) secara langsung atau nyata terkait dengan peristiwa atau tradisi hidup, dengan ide, atau dengan kepercayaan, dengan karya seni dan sastra yang mempunyai signifikansi universal luar biasa (Labadi, 2013: 42). Untuk memperkuat informasi tentang warisan sejarah dan budaya yang diusulkan harus didukung dengan naskah akademik dan komponen pendukung seperti foto dan film dokumenter. Persyaratan tidak sulit dipenuhi karena sumbersumber informasi berbasis kajian ilmiah mengenai garam palung pada saat itu masih relatif langka.

Kemajuan yang lebih besar diperlihatkan oleh petani garam palung di Amed. Di pesisir ini ada 5 kelompok petani garam yang telah dibentuk pada 2010, yaitu Tasik Segara, Buana Sari, Wisnu Sari, Karang Sari, dan Sari Laut. Mereka telah mendapatkan perhatian dari sebuah organisasi yaitu Indonesia-Swiss Intellectual Property Project (ISIP). Sejak 2014 ISIP memberikan pendampingan kepada petani garam Amed. ISIP juga mensponsori studi banding ke Perancis pada 8-12 September 2014. Ada tiga orang petani garam Amed yang ikut ke Perancis yaitu I Nengah Suanda, I Nyoman Patra Gunawan, dan I Ketut Telaga. Mereka didampingi oleh perwakilan dari Direktorat Jenderal Hak Kekayaan Inteletual Kementerian Hukum dan Hak Asasi Manusia, yaitu Dr. Ir. H. Riyaldi, M.M. (Tim Ahli Indikasi Geografis) dan Gunawan S.Si. (Staf Teknis Evaluasi Indikasi Geografis); dari Dinas Perindustrian dan Perdagangan Kabupaten Karangasem yaitu I Wayang Swindia, S.Sos., M.A.P. (Kepala Seksi Perlindungan Konsumen), dan Kepala Desa Purwakerthi I Wayang Sentuni Artana). Sementara itu wakil dari ISIP adalah Mr. Daniel Lauchenauer, sedangkan wakil dari Aubard Consulting terdiri atas Audrey Aubard dan Charles Perraud. Salah satu lokasi di Perancis yang dikunjungi Guérande, desa penghasil garam. Garam dari desa ini dijual melalui koperasi Les Salines de Guérande baik dalam bentuk garam maupun produk olahan yang menggunakan garam Guérande sebagai bumbu. Desa Guérande telah berhasil mengembangkan garam sehingga menjadi sumber pendapatan utama bagi para petani. Hal itu karena mereka telah mendapatkan Sertifikat Indikasi Geografis sehingga garam Guérande memiliki jaminan kualitas dan terlindungi dari pemalsuan (Tim Study Tour Garam Amed Bali, 2014). Mengambil insiprasi dari Guérande, ISIP mendorong petani garam Amed untuk mendapatkan Sertifikat Indikasi Geografis. Mereka kemudian membentuk Masyarakat Perlindungan Indikasi Geografis (MPIG) Garam Amed. Pada 2015 mereka berhasil mendapatkan Sertifikat Indikasi Geografis dari Kementerian Hukum dan Hak Asasi Manusia RI. Dengan sertifikat itu garam palung Amed mendapat pengakuan sebagai produk yang unik dan karena itu memiliki nilai jual yang tinggi. Keberhasilan mendapatkan Sertifikat Indikasi Geografis sudah barang tentu akan membantu kelestarian teknologi garam palung.

Perhatian terhadap kelestarian teknologi garam palung diperlihatkan juga oleh Hotel Uyah Amed \& Spa-Resort. Didasari keprihatian terdesaknya garam Amed oleh perkembangan pariwisata, pihak manajemen hotel ini memiliki gagasan untuk mengemas proses produksi garam palung sebagai atraksi wisata. Manajemen hotel ini menyediakan halaman belakang yang langsung berbatasan dengan laut sebagai area produksi garam lengkap dengan semua peralatan yang diperlukan termasuk gudang penyimpanan garam. Proses produksi dikerjakan oleh dua orang petani dengan sistem bagi hasil sama besar. Pada saat musim garam, wisatawan yang menginap di hotel itu atau berkunjung ke restoran mendapat suguhan atraksi yang tidak mereka temukan di tempat lain. Mereka dapat ikut berpatisipasi membuat garam bersama petani atau sekadar menonton. Hal lain yang menarik adalah manajemen hotel ini berkeinginian untuk mempertahankan keaslian teknologi garam palung. Oleh karena itu proses produksi garam palung di hotel ini tidak menggunakan perlatan mesin pompa air, selang atau geomembran (Wawancara dengan Sudana, 10 Februari 2019). Di sebelah Hotel Uyah terdapat restoran yang juga bertema garam palung. Tamu yang berkunjung ke restoran ini akan mendapatkan informasi dasar mengenai garam palung Amed yang tertulis pada buku menu, selain melaui foto- 
foto dan contoh produk garam yang dipajang di sebuah meja di dekat pintu masuk.

Berbeda dari Tejakula dan Amed, menurunnya usaha garam palung Pasca-PUGAR di Kusamba tampknya belum mendapat perhatian dari banyak pihak termasuk pemerintah. Sampai pada 2018 hanya ada dua kelompok petani garam palung yang masih bertahan, yaitu Amarta Segara dan Sarining Segara. Kedua kelompok itu berada di Banjar Batur. Jejak lain yang masih tersisa dari program PUGAR di petasikan ini adalah penggunaan geomembran untuk melapisi dasar palung oleh beberapa petani garam. Di antara ketiga petasikan yang dibicarakan dalam artikel ini, hanya petani di Kusamba yang mau menggunakan geomembran dalam proses produksi garam palung (Wawancara dengan I Wayan Rena, 2018). Akan tetapi, penggunaan teknologi baru itu justru menciptakan kesulitan bagi petani garam setempat untuk memasarkan produk mereka. Di Kabupaten Klungkung ada sebuah perusahaan garam yaitu PT Bening yang berlokasi di Jumpai, Kecamatan Klungkung. Perusahaan ini hanya membeli garam yang diproduksi secara tradisional dengan teknologi palung untuk memenuhi permintaan hotel-hotel dan restoran-restoran besar di Bali, Sumatra, dan Kalimantan. Mereka menginginkan garam yang bebas dari unsur kimia. PT Bening menerapkan standar yang ketat untuk garam yang akan dibeli, yaitu tidak diproduksi dengan menggunakan karet, spons atau plastik dan tidak diodisasi. Oleh karena itu, perusahaan itu lebih memilih untuk membeli garam palung dari Gerokgak di Kabupaten Buleleng. Garam palung dari Kusamba dianggap tidak memenuhi standar perusaahan itu karena diproduksi dengan palung yang telah dilapisi geomembran (http://industri.bisnis.com /read/20151215/99/501989/produksi-me-num puk-petani-garam-di-klungkung-mengeluh, diakses pada 9 Februari 2019).

\section{SIMPULAN}

Teknologi garam palung merupakan manifetasi dari falsafah Tri Hita Karana dalam aktivitas pembuatan garam di Bali. Teknologi produksi garam ini sangat khas dan hanya merupakan satusatunya di Indonesia atau bahkan di dunia. Teknologi garam palung telah digunakan dari generasi ke generasi. Perkembangan industri pariwisata telah menyebabkan teknologi garam palung semakin terdesak sehingga terancam kelestariannya. Namun, masalah ini telah mendapatkan perhatian dari para pemangku kepentingan yang diwujudkan melalui berbagai kegiatan yang secara langsung maupun tidak langsung dapat memberi sumbangan penting untuk mempertahankan eksistensi teknologi garam palung sebagai warisan sejarah masyarakat pesisir Bali.

Kehadiran industri pariwisata hingga ke wilayah petasikan memang tidak dapat ditolak. Kegiatan-kegiatan yang dilakukan oleh para pemangku kepentingan melestarikan teknologi garam palung terutama di Amed dan Tejakula bahkan diintegrasikan dengan pariwisata. Di kedua petasikan itu telah mulai dikembangkan ekowisata garam palung kendati masih dalam tahap yang paling awal. Ekowisata dapat dikatakan sebagai bentuk perlawanan terhadap pariwisata massal yang telah menimbulkan kerusakan lingkungan dan pada akhirnya merugikan petani garam sendiri. Ekowisata juga lebih ramah lingkungan dan menguntugkan semua pihak karena dikelola dengan melibatkan paritisipasi masyarakat mulai dari perencanaan sampai pelaksanaan.

\section{CATATAN}

1"Pemunder Desa Adat Culik (Bhisama Desa Adat Culik) Translit Berbahasa Indonesia”, hlm. 1. Pada bagian akhir pemunder ini terdapat keterangan bahwa versi tertua Pemunder Desa Adat Culik ditulis dalam bahasa dan huruf Bali. Penulisannya diselesaikan pada Rabu Umanis, Wuku Prangbakat, Titi Tanggal ping 11 (Solas), Sasih Kesepuluh, Içaka 1500, di Pura Mbudan Toya. Pemunder ini ditransliterasi ke dalam bahasa Bali dengan huruf Latin yang diselesaikan pada Rabu Umanis, Wuku Tambir, Panglong ping 15 (Tileming), Sasih Ketiga, Içaka 1922. Pemunder ini kemudian diterjemahkan ke dalam bahasa Indonesia oleh Ida Bagus Gede Jelantik, S.Pd., S.Ag. dari Gria Jelantik Manuaba, Desa Sibang Kaja, Kecamatan Abiansemal, Kabupaten Badung. Penerjemahan diselesaikan pada Jumat Pon Juluwangi, 14 September 2001. "Pemunder Desa Adat Culik", hlm. 24. 
2Para ahli areologi menduga bahwa solar evaporation merupakan metode pembuatan garam yang paling awal digunakan untuk menghasilkan garam dalam jumlah yang lebih banyak. Metode ini dikembangkan dengan meniru proses evaporasi alamiah-tanpa campur tangan manusia-yang telah dikenal sejak periode prakomersial. F.P. Rose, "Primitive Salt Works", The Arkansas Historical Quarterly, Vol. 11 (4), Winter 1952, hlm. 315-316.

${ }^{3}$ Bangkrak adalah alat untuk mengukur (menggaruk) tanah sari. Bangkrak dibuat dari papan kayu yang diberi jari-jari dari besi menyerupai garpu dan diberi tangkai yang panjang dari bambu.

4"Duplikat Prasasti Pura Mbudan Toya”. Dokumen milik Desa Adat Culik ini merupakan transliterasi dari prasasti Pura Mbudan Toya dari bahasa dan huruf Bali ke dalam bahasa Bali dengan huruf Latin.

${ }^{5}$ Kesulitan itu berkaitan dengan cara warga desa adat memperlakukan sumber-sumber tradisi tentang desa mereka sebagai pusaka yang sakral sehingga disimpan di tempat yang suci. Sumbersumber itu hanya dapat dibaca pada saat tertentu (dalam suatu upacara) oleh orang yang berasal dari golongan yang memiliki otoritas dalam urusan keagamaan. Seandainya sumber-sumber itu dapat diakses, tentu juga diperlukan studi tersendiri untuk dapat membaca dan memahaminya karena ditulis dalam bahasa dan huruf Bali pada media rontal. Sejauh ini tim peneliti baru memperoleh sumber-sumber yang telah ditransliterasi ke dalam bahasa Bali dan bahasa Indonesia dengan huruf Latin, dan terbatas menyangkut Desa Adat Culik.

${ }^{6}$ Diolah dari data dalam "Kegiatan Pemberdayaan Usaha Garam Rakyat (PUGAR) TA. 2011”, "Dokumen Pelaksanaan BLM PUGAR TA. 2011 di Satker 220530 Kabupaten Karangasem-Bali”, dan "Laporan Kegiatan PUGAR Kabupaten Karangasem TA 2014”. Arsip Dinas Peternakan, Kelautan dan Perikanan Kabupaten Karangasem. ${ }^{7}$ Palemahan desa adat terdiri atas karang ayahan atau tegak desa dan wawengkon atau wewidangan. Karang ayahan adalah tempat krama (warga) desa membangun rumah tinggal. Wawengkon adalah wilayah desa, yang terdiri atas tanah desa dan tanah gunakaya atau tanah milik pribadi. Wayan P. Windia, Bali Mawacara:
Kesatuan Awig-awig, Hukum dan Pemerintahan di Bali (Denpasar: Udayana University Press, 2008), hlm. 19.

\section{UCAPAN TERIMA KASIH}

Penelitian ini merupakan bagian dari penelitian Strategis Nasional Konsorsium yang berjudul "Preservasi Teknologi Palung dalam Pembuatan Garam Berbasis Kearifan Lokal untuk Pengembangan Wisata Bahari di Kabupaten Buleleng, Bali," yang didanai oleh Direktorat Riset dan Pengabdian kepada Masyarakat, Kementerian Riset Teknologi dan Pendidikan Tinggi Republik Indonesia Tahun Anggaran 2018.

\section{REFERENSI}

Bogdan, Robert C. \& Biklen Sari Knopp (1982). Qualitative Research for Education: An Introduction to Theory and Methods. Boston: Allyn and Bacon, Inc.

Consuelo G. Sevilla et al. (1993). Pengantar Metode Penelitian. Jakarta: Penerbit Universitas Indonesia.

David Kaplan \& Albert A. Manners (2000). Teori Budaya, terjemahan Landung Simatupang. Yogyakarta: Pustaka Pelajar.

Direktorat Pemberdayaan Masyarakat Pesisir dan Pengembangan Usaha Kementerian Kelautan dan Perikanan Republik Indonesia (2011). Pemberdayaan Usaha Garam Rakyat. Jakarta: Direktorat Pember-dayaan Masyarakat Pesisir dan Pengem-bangan Usaha Kementerian Kelautan dan Perikanan Republik Indonesia.

Direktorat Pemberdayaan Masyarakat Pesisir dan Pengembangan Usaha Direktorat Jenderal Kelautan, Pesisir dan Pulau-pulau kecil (KP3K) Kementerian Kelautan dan Perikanan Republik Indonesia (2012). "PUGAR Merenda Asa”. Semarang: Pusat Studi Asia Fakultas Ilmu Budaya Universitas Diponegoro.

Gilmore, Harlan W. (1955). "Cultural Diffusion Via Salt”, American Anthropologist, Vol. 57 (5):1011-1015.

Kaplan, David dan Albert A. Maners (2000). Teori Budaya, terjemahan Landung Simatupang. Yogyakarta: Pustaka Pelajar. 
Kurnianingsih, A. (2008). Simulacra Bali: Ambiguitas Tradisionalisasi Orang Bali. Yogyakarta: Insist Press.

Labadi, Sophia. 2013. UNESCO, Cultural Heritage, and Outstanding Universal Value: Value-based Analyses of the World Heritage and Intangible Cultural Heritage Conventions. Lanham: AltaMira Press.

Putra-Agung, Anak Agung Gde (2001). Peralihan Sistem Birokrasi dari Tradisional ke Kolonial. Yogyakarta: Pustaka Pelajar.

Rochwulaningsih, Yety (2012). Marjinalisasi Petani Garam Indonesia. Semarang: Madina Press.

Rochwulaningsih, Yety dan Mahendra P. Utama (2013). Tipologi Sosiokultural Petambak Garam di Indonesia, Jilid I. Semarang: Undip Press.

Rochwulaningsih, Yety (2013). Ekspansi Ekonomi Global pada Garam Rakyat. Semarang: Undip Press.

Rochwulaningsih, Yety (2017). Membongkar Ketidakadilan Struktural dalam Usaha Garam Rakyat melalui Perspektif Sosiologi Sejarah Guna Mewujudkan Kesejahteraan Petambak Garam dan Swasembada Garam Nasional. Semarang: Undip Press.

Rochwulaningsih, Yety (2018). Salt Production Business Potential in Aceh as Capital for the Coastal Communities Welfare. Journal of Maritime Studies and National Integration, Vol. 2 (1): 23-30.

Rodriguez, Jeanette \& Ted Fortier (2007). Cultural Memory: Resistance, Faith, and Identity. Austin: University of Texas Press.

Rose, F. P. (1952). "Primitive Salt Works", The Arkansas Historical Quarterly, Vol. 11 (4): 315-326.

Surpha, I Wayan (2004). Eksistensi Desa Adat dan Desa Dinas di Bali. Denpasar: Pustaka Bali Post.

Tim Study Tour Garam Amed Bali (2014). "Laporan Study Tour Bali Amed Salt to Guérande (France) for Decision Makers to Strengthening the Amed Salt GI Suplly Chain Indonesia-Swiss Intelectual Property Project (ISIP) Nantes, Perancis, 8-12 September 2014". Tidak diterbitkan.
Windia, Wayan P. (2008). Bali Mawacara: Kesatuan Awig-awig, Hukum dan Pemerintahan di Bali. Denpasar: Udayana Press.

Yogana, I Putu Bagus, I Gede Setiawan Adi Putra, dan Nyoman Parining (2016). "Potensi dan Proses Pemberdayaan Petani Garam di Desa Kusamba Kecamatan Dawan Kabupaten Klungkung", Agribisnis dan Agrowisata 5(3): 588-596.

"Digempur Investor Pariwisata, Lahan Petani Garam di Karangasem Kian Terkikis", Tribun Bali, 11 Agustus 2017.

"Dokumen Pelaksanaan BLM PUGAR TA. 2011 di Satker 220530 Kabupaten KarangasemBali”. Dinas Peternakan, Kelautan dan Perikanan Kabupaten Karangasem.

"Duplikat Prasasti Pura Mbudan Toya. Dokumen Desa Adat Culik.

"History of Salt", http://www.saltinstitute.org /38.html, diakses pada 22 Desember 2017.

"Karangasem the Spirit of Bali". Brosur wisata. Dinas Pariwisata Kabupaten Karangasem.

"Kegiatan Pemberdayaan Usaha Garam Rakyat (PUGAR) TA. 2011”. Dinas Peternakan, Kelautan dan Perikanan Karangasem.

"Laporan Kegiatan PUGAR Kabupaten Karangasem TA 2014”. Dinas Peternakan, Kelautan dan Perikanan Kabupaten Karangasem.

"Pemunder Desa Adat Culik" (Bhisama Desa Adat Culik) Translit Berbahasa Indonesia. Dokumen Desa Adat Culik.

"Produksi Menumpuk Petani Garam di Klungkung Mengeluh", http://industri. bisnis. com $/ \mathrm{read} / 20151215 / 99$ /501989/produksimenumpuk-petani-garam-di-klungkungmengeluh, dikunjungi pada 2018.

“Tasik”, http://dictionary.basabali.org/Tasik, di kunjungi pada 10 Februari 2019.

\section{DAFTAR INFORMAN}

Sinupring, Desa Kusamba, Klungkung. I Wayang Rena, Desa Kusamba, Klungkung. Ida Wayan Gangga, Desa Purwakerthi, Karangasem.

Nengah Suande, Desa Purwakerthi, Karangasem.

Nengah Nungkrah, Desa Purwakerthi, Karangasem.

Sudana, Desa Purwakerthi, Karangasem. 